\title{
Studi Korelasi Disiplin Dalam Pembelajaran Dengan Kinerja Guru Di SMAN Se- Kecamatan Bumi Agung Kabupaten Way Kanan
}

\author{
Marlina $^{1 *}$ \\ ${ }^{1}$ STKIP Nurul Huda OKU Timur \\ *marlina@stkipnurulhuda.ac.id
}

\begin{abstract}
Abstrak
Tujuan penelitian ini adalah ingin mengetahui apakah ada korelasi positif dan signifikan antara Disiplin dalam Pembelajaran dengan Kinerja Guru SMAN Se- Kecamatan Bumi Agung Kabupaten Way Kanan. Sehingga dapat digunakan sebagai sumbangsih pemikiran dan informasi serta pengetahuan dalam rangka meningkatkan keberhasilan pembelajaran. Populasi dalam penelitian ini adalah guru pada SMAN se kecamatan Bumi Agung dengan pengambilan sampel menggunakan metode slovin berjumlah 30 orang. Teknik sampling yang digunakan adalah dispropotional stratified random sampling. Instrumen yang digunakan untuk menjaring data adalah kuesioner model skala likert yang telah diuji validitas dan reliabilitasnya. Hipotesis diuji dengan teknik korelasi sederhana dan Regresi.

Berdasarkan hasil temuan penelitian dapat disimpulkan bahwa: ada korelasi positif dan signifikan disiplin dalam pembelajaran dengan kinerja guru SMAN dengan tingkat keeratan hubungan cukup $(0,486)$. Adapun kontribusi disiplin dalam pembelajaran sebesar koefisien parsial R2 $=0,236$ atau sebesar $23,6 \%$ terhadap kinerja guru. Persamaan regresinya $Y^{\prime}=52,705+0,55(80)=96,705$ ( maksimum 150) bahwa : (d) ada pengaruh positif dan signifikan antara disiplin dalam pempelajaran terhadap kinerja guru.
\end{abstract}

Kata kunci: Disiplin dalam Pembelajaran, Kinerja Guru

\section{PENDAHULUAN}

Pendidikan merupakan sesuatu yang penting dan utama dalam konteks pembangunan bangsa dan negara. Pendidikan pada hakikatnya adalah usaha membudayakan manusia atau memanusiakan manusia. Hal ini dapat terlihat dari tujuan nasional bangsa Indonesia yang salah satunya yaitu mencerdaskan kehidupan bangsa yang menempati posisi strategis dalam pembukaan UUD 1945. Dalam situasi pendidikan, khususnya pendidikan formal di sekolah, guru merupakan komponen yang penting dalam meningkatkan mutu pendidikan. Ini disebabkan guru berada di barisan terdepan dalam pelaksanaan pendidikan. Dengan kata lain, guru merupakan komponen yang paling berhubungan dengan terciptanya proses dan hasil pendidikan yang berkualitas. Dengan demikian upaya perbaikan apapun yang dilakukan untuk meningkatkan pendidikan tidak akan memberikan sumbangan yang signifikan tanpa didukung oleh guru yang profesional dan berkompeten.

Guru dalam proses pembelajaran memegang peranan yang sangat penting. Peran guru tersebut belum dapat diganti dan diambil alih oleh apa pun. Hal ini disebabkan oleh unsur-unsur manusiawi yang tidak dapat diganti oleh unsur lain. Guru menjadi sosok dan tokoh teladan yang dicontoh oleh peserta didik dan masyarakat pada umumnya.

Guru diibaratkan nahkoda sebuah kapal yang mengarahkan hendak kemana kapal akan berlayar sampai ketujuan yang diharapkan. Begitu juga dalam pendidikan. Guru memiliki peranan yang sangat penting dalam meningkatkan mutu pendidikan dalam rangka mencapai tujuan pendidikan nasional. Guru dalam upaya meningkatkan mutu pendidikan dituntut memiliki kinerja yang mampu memberikan dan merealisasikan harapan dan keinginan berbagai pihak terutama masyarakat pada umumnya yang mempercayakan pendidikan anak kepada guru dan Sekolah.

Mutu dan tujuan pendidikan sangat berhubungan dengan kinerja guru dalam melaksanakan tugasnya. Guru merupakan pribadi yang berkembang, guru pada prinsipnya memiliki potensi yang 
cukup tinggi untuk berkreasi meningkatkan kinerjanya. Upaya meningkatkan kinerja guru tidak selalu berjalan lancar dan wajar, hal ini disebabkan adanya berbagai faktor yang muncul baik dari pribadi guru sendiri maupun dari luar pribadi guru. Faktor dari pribadi guru diantaranya adalah disiplin guru.

Berkenaan dengan disiplin pembelajaran, seorang guru yang profesional dituntut mempunyai kemampuan yang tinggi untuk melaksanakan pekerjaan yang menjadi tanggung jawabnya tepat pada waktunya dengan hasil yang baik. Disiplin guru merupakan salah satu faktor dalam upaya peningkatan kinerja guru di pendidikan. Guru sebagai suritauladan bagi peserta didik, sehingga kepribadian guru cenderung ditiru. Apakah jadinya jika disiplin guru ketika hadir di sekolah rendah. Sebagai contoh guru sering datang terlambat ke sekolah, guru masuk kelas terlambat dan mengakhiri pelajaran sebelum pembelajaran selesai. Sikap guru tersebut tentunya tidak layak ditiru oleh peserta didik. Kedisiplinan guru tentunya sangat berhubungan dengan kinerja guru dalam pembelajaran.

Berdasarkan uraian di atas maka dirasa perlu melakukan penelitian tentang :"Studi Korelasi Disiplin dalam Pembelajaran Dengan Kinerja Guru Di SMAN Se- Kecamatan Bumi Agung Kabupaten Way Kanan".

\section{METODE/EKSPERIMEN}

Penelitian ini menggunakan pendekatan kuantitatif yang menekankan analisisnya pada data data numerikal (angka) yang diolah dengan metode statistika. Pendekatan kuantitatif dilakukan dalam rangka pengujian hipotesis dan menyandarkan kesimpulan hasilnya pada suatu probabilitas kesalahan penolakan hipotesis nihil (Edi Kusnadi, 2005:29).

Sifat penelitian ini adalah korelasi, yaitu menunjuk pada hubungan antar variabel yang berdiri sendiri, eksistensinya variabel - variabel dalam penelitian dimungkinkan terdapat keterkaitan dalam bentuk hubungan (T.Widodo, 2009:21). Penelitian ini berusaha melihat hubungan antara disiplin dalam pembelajaran dengan kinerja guru.

Variabel terikat dalam penelitian ini adalah kinerja guru, sedangkan variabel bebasnya adalah disiplin dalam pembelajaran. Penulis akan menghitung sejauh mana korelasi disiplin dalam pembelajaran dengan kinerja guru di SMAN Se- KecamatanBumi Agung Kabupaten Way Kanan.

\section{HASIL DAN PEMBAHASAN}

Pembahasan hasil penelitian Studi Korelasi Disiplin dalam Pembelajaran dengan Kinerja Guru di SMAN se Kecamatan Bumi Agung Kabupaten Way Kanan difokuskan pada: Korelasi positif dan signifikan Disiplin dalam Pembelajaran dengan Kinerja guru. Secara lebih lanjut pembahasan hasil analisis data dan interpretasi data yang telah disajikan, terkait dengan permasalahan dan tujuan penelitian.

Tabel . Hasil Analisa Data Hipotesis

\begin{tabular}{|c|l|l|l|l|l|l|}
\hline Variabel & $r$ hitung & $r$ tabel & Sig. $(<0,05)$ & Determinasi & $\begin{array}{l}\text { Interval } \\
\text { Kekuatan }\end{array}$ & Ket. \\
\hline $\mathrm{X}$ & 0,486 & 0,361 & $0,006<0,05$ & $23,6 \%$ & $\begin{array}{l}\text { Antara } \\
0,40-0,60 \quad= \\
\text { cukup/sedang }\end{array}$ & $\begin{array}{l}\text { Hipotesis } \\
\text { diterima }\end{array}$ \\
\hline
\end{tabular}

Pengujian hipotesis dalam penelitian ini diterima dimana ada korelasi yang positif dan signifikan antara disiplin dalam pembelajaran dengan kinerja guru. Diketahui $r$ hitung 0,486 lebih dari $r$ tabel dengan $n=30$ sebesar 0,361 dengan Kriteria uji: Tolak Ho jika rhit $\geq$ rtabel pada taraf signifikansi $\alpha=$ $5 \%$. Penafsiran koefisien determinasi adalah sebesar $23,6 \%$ hal ini menunjukkan bahwa Kinerja guru dapat dijelaskan oleh disiplin dalam pembelajaran hanya sebesar $23,6 \%$ sedangkan $76,4 \%$ kinerja guru dijelaskan oleh yang lainnya.

Hipotesis penelitian ini yang menyatakan terdapat korelasi positif dan signifikan antara disiplin dalam pembelajaran dengan kinerja guru di SMAN se Kecamatan Bumi Agung Kabupaten Way 
Kanan dapat diterima sesuai dengan teori yang dikemukakan.

Disiplin dalam pembelajaran merupakan unsur dari kompetensi kepribadian untuk itu kompetensi ini juga berintegrasi dengan kinerja guru. Disiplin dalam pembelajaran guru adalah bentuk prilaku dan karakter seorang guru yang mencerminkan keteraturan hidupnya. Hal ini sejalan dengan Syafrudin Nurdin dan Basyiruddin usman dalam Buku Guru Profesional dan Implementasi Kurikulum, "seorang pengajar mampu mengoranisasikan waktu dalam proses belajar mengajar dan mampu menggunakan secara maksimum waktu pengajaran yang telah dialokasikan (Syafrudin Nurdin dan Basyirudin Usman, 2003: h.111).

Kedisiplinan sangat ditekankan sesuai dengan firman Allah surat Asy-Syarh : 7-8

$$
\text { فَإِذَا فَرَغْتَ فَانْصَبْ ِ }
$$

Artinya: Maka apabila kamu telah selesai (dari sesuatu urusan), kerjakanlah dengan sungguhsungguh (urusan) yang lain. Dan hanya kepada Tuhanmulah hendaknya kamu berharap (Depag RI, 2009: h.596).

Ayat tersebut menurut (Harun Yahya ,2003:h.67), berarti manusia tidak menyia-nyiakan waktu dan bersegera berbuat kebaikan dengan gairah besar. Manusia tidak menganggap usahanya sudah cukup. Manusia tidak pernah lupa bahwa mereka harus mempertanggungjawabkan atas setiap detik waktu yang digunakan di dunia.

Artinya guru sebagai pendidik dan teladan dapat memanagemen waktu sesuai proporsinya sebagai guru di sekolah, sebagai keluarga di rumah dan sebagai anggota masyarakat dilingkungannya, dan dapat melaksanakan tugasnya dengan penuh tanggung jawab dan berusaha mengoptimalkan hasil kerja semaksimal mungkin untuk peningkatan pembelajaran sehingga mutu pendidikan terealisasi. Guru juga bertanggung jawab atas segala pekerjaannya sesuai dengan norma dan aturan yang ada.

Berdasarkan interviw dan obeservasi dan didukung skor hasil angket yang menunjukkan keadiran guru 56,64\% tidak tepat waktu , 77,8 \% guru tidak tepat memulai dan mengakhiri pembelajaran, $70 \%$ guru belum taat terhadap peraturan di sekolah dari 30 responden tergolong masih rendah. Menurut kepala sekolah alasan guru terlambat adalah masih rendahnya kesadaran pentingnya kedisiplinan, dan Alasan lain rendahnya disiplin guru berdasarkan jarak tempat tinggal dengan sekolah sebenarnya bervariatif antar $500 \mathrm{M}-40 \mathrm{KM}$, jarak menurut kepala sekolah tidak menjadi pengaruh terlambatnnya guru datang ke sekolah asalkan guru dapat mengatur waktu dengan baik. Terkadang menurut Kepala Sekolah yang rumahnya dekat sering terlambat karena mereka mengerjakan pekerjaan lain. Alasan keterlambatan bagi guru yang jarak rumahnya jauh adalah cuaca dan kendaraan yang digunakan rusak.

Interview yang penulis peroleh dapat penulis simpulkan bahwa rendahnya kedisiplinan guru dikarenakan rendahnya motivasi masing - masing guru dalam disiplin hal ini berkenaan dengan pendidikan dan pengalaman yang dimiliki. Hal ini mengindikasikan rendahnya tingkat kinerja berhubungan dengan disiplin guru dalam pembelajaran.

Persamaan regresi menunjukkan koefisien $X$ bernilai positif sebesar 0,55 yang berarti ada pengaruh positif (berjalan searah) antara disiplin dalam pembelajaran berpengaruh terhadap kinerja guru.

Berdasarkan interview dan observasi dan didukung skor hasil angket yang menunjukkan kinerja guru $77,08 \%$ rendah dalam membuat perencanaan pembelajaran, 61,07 \% rendah dalam pelasanaan pembelajaran, 56,67 \% cukup rendah dalam penilaian pembelajaran. Berdasarkan observasi yang dilakukan oleh peneliti bahwa dari ke dua SMAN semua guru sudah membuat perencanaan pembelajaran di awal ajaran baru. Hasil observasi dalam pelaksanaan pembelajaran yang peneliti amati dari kedua SMAN pada intinya setiap guru dalam pembelajaran melakukan kegiatan pendahuluan, inti dan penutup hanya belum optimal sesuai dengan teori yang dikemukaan. Sedangkan hasil interview dan observasi mengenai penilaian pembelajaran yang dilakukan peneliti. Guru telah melaksanakan penilaian terbukti melalui dokumen tertulis berupa lembar kerja siswa, 
daftar nilai dan leger atau rapot.

Berdasarkan pengamatan tersebut kinerja guru dalam pembelajaran yang terkait dengan disiplin guru masih tergolong rendah. Kemampuan guru dalam mendesain perencanaan pembelajaran, melaksanakan pembelajaran dan melakukan penilaian masih terbilang rendah. Kemampuan guru dalam mengorganisir waktu juga belum optimal dan proporsional dalam mendesain perencanaan pembelajaran, melaksanakan pembelajaran dan penilaian pembelajaran.

Hipotesis penelitian ini yang menyatakan terdapat korelasi positif dan signifikan disiplin dalam pembelajaran dengan kinerja guru di SMAN se Kecamatan Bumi Agung Kabupaten Way Kanan dapat diterima sesuai dengan teori yang dikemukakan Popi Sopiatin bahwa kinerja merupakan unjuk kerja seseorang yang didasari oleh pengalaman, pengetahuan dan keterampilan untuk melakukan suatu pekerjaan, sehingga kinerja di dalamnya mengandung unsur kompetensi. (Popi Sopiatin, 2010: h. 62)

Penulis dapat menyimpulkan bahwa disiplin dalam pembelajaran berkorelasi dengan kinerja guru. Kinerja guru berupa aktivitas, prilaku dan produktifitas dalam pembelajaran merupakan realisasi dari kompetensi yang dimiliki guru dalam disiplin dalam pembelajaran yang juga merupakan unsur dari kompetensi kepribadian.

Pendapat lain yang sesuai bahwa kinerja berhubungan dengan disiplin dalam pembelajaran menurut Sutermeister, bahwa: Prestasi kerja itu sendiri 10-20 \% bergantung pada kemampuannya. (Rusman, 2011:h.52) Pendapat tersebut 10-20 \% bisa dikatakan kinerja guru bergantung dengan kemampuan guru yang dimiliki sehingga kinerja guru dalam pembelajaran dapat meningkat bila kompetensi dalam disiplin guru ditingkatkan dengan optimal.

Sedangkan berdasarkan hasil regresi menunjukan ada pengaruh positif antara disiplin dalam pembelajaran dengan kinerja guru . Artinya jika disiplin dalam pembelajaran ditingkatkan maka akan meningkat pula kinerja guru dalam pembelajaran. Jika guru SMAN meningkatkan disiplinnya dalam pembelajaran melalui pengaturan waktu secara optimal dan pembagian waktu secara proporsional dalam pembelajaran maka kinerja guru dalam pembelajaran akan meningkat hal ini juga dapat berpengaruh terhadap mutu pendidikan.

\section{PENUTUP}

Berdasarkan hasil analisa data dan pembahasan hasil penelitian, dapat ditarik kesimpulan penelitian yang dilakukan diperoleh data sebagai berikut :

Ada korelasi positif dan signifikan Disiplin dalam Pembelajaran dengan Kinerja Guru SMAN se Kecamatan Bumi Agung Kabupaten Way Kanan, dengan tingkat koefisiensi korelasi $r_{\text {hitung }} 0,486>r$ tabel 0,361 dengan signifikansi $0,006<0,05$. Sehingga secara deskriptif memiliki tingkat korelasi sedang. Koefisien determinasi $23,6 \%$ perubahan variabel kinerja guru dapat diterangkan oleh Disiplin dalam Pembelajaran.

Persamaan regresi menunjukkan ada pengaruh yang positif antara kompetensi profesional dan disiplin dalam pembelajaran dengan kinerja guru dengan persamaan $Y^{\prime}=52,705+0,55(80)=$ 96,705 (maksimum 150). Artinya jika disiplin dalam pembelajaran ditingkatkan mencapai nilai optimal maka kinerja guru akan meningkat.

Semakin tinggi tingkat kedisiplinan guru maka akan semakin meningkatkan dan menunjukkan hasil kinerja guru yang optimal dalam pembelajaran sehingga mutu pendidikan dapat terwujut

\section{UCAPAN TERIMAKASIH}

Ucapan terima kasih kepada Bpk. Erwin, M.Pd. selaku Ketua STKIP Nurul Huda, Bpk. Suhartono, M.Pd.I. selaku Ketua Program Studi Pendidikan Agama Islam, Kepala sekolah dan dewan guru SMA N Bumi Agung, dan semua pihak yang telah banyak membantu. 


\section{DAFTAR PUSTAKA}

Anas Sudijono, Pengantar Statistika Pendidikan, Jakarta: PT Raja Grafindo Persada,2004.

Depag RI, Al Qur'an dan Terjemahnya, Bandung: PT Sygma, 2009.

Depdiknas RI, UU RI No.20 Tahun 2003 Tentang Sisdiknas, Jakarta, 2005.

Depdiknas, Kamus Bahasa Indonesia, Jakarta: Pusat Bahasa, 2008. Kamus Besar Bahasa Indonesia, Edisi Ke 3, Jakarta : Pusat Bahasa, 2003.

Edi Kusnadi, Metode Penelitian, Jakarta: Ramayana Press, 2005.

Fitri R. Ghozally, Kesuksesan Dalam Karir Dan Kepemimpinan, Jakarta:Edsa Mahkota,2005.

Freyadefunk, " Cara Menguji Normalitas Data Dengan SPSS", dalam http://freyadefunk.wordpress.com 24 Maret 2015.

Hamzah B Uno, Orientasi Baru Dalam Psikologi Pembelajaran, Jakarta : Bumi Aksara, 2012.

Harun Yahya, Semangat dan Gairah Orang-orang Beriman, Surabaya: Risalah Gusti,2003.

Hendry, "Populasi dan Sampel", dalam http://teorionline.wordpress.com 21 Maret 2015

Kunandar, Guru Profesional:Implementasi Kurikulum Tingkat Satuan Pendidkan Dan Sukses Dalam Sertifikasi Guru , Jakarta: Raja Grafindo Persada,2007.

Moch. Uzer Usman, Menjadi Guru Profesional, Bandung: PT. Remaja Rosdakarya,2005.

Moh. Pabundu Tika, Budaya Organisasi dan Peningkatan Kinerja Perusahaan, Jakarta : Bumi aksara, 2006.

Nana Sudjana, Dasar-Dasar Proses Belajar Mengajar, Bandung: Sinar Baru, 1989.

Ondi Saondi dan Aris Suherman, Etika Profesi Keguruan, Bandung: PT Refika Aditama, 2010.

Popi Sopiatin, Manajemen Belajar Berbasis Kepuasan Siswa, Bogor:Ghalia Indonesia, 2010.

Quraisy Shihab, Tafsir AL-Misbah :Pesan Kesan dan Keserasian Al Qur'an, Jakarta : Lentera Hati, 2002.

Ronnie Wicaksono, "Menentukan Jumlah Sampel Dengan Rumus", dalam http://analisisstatistika.blogspot.com. Maret 2015.

Rusman, Model-model Pembelajaran, Jakarta: PT Grafindo Persada, 2011.

Siswanto Sastrohadiwiryo, Manajemen Tenaga Kerja Indonesia, Jakarta : Bumi Aksara, 2005.

Sondang P. Siagian, Manajemen Sumber Daya Manusia, Jakarta : Bumi Aksara, 2007.

Sri Anitah W, Strategi Pembelajaran di SD, Jakarta: Penerbit Universitas Terbuka, 2008.

Sugiyono, Metode Penelitian Pendidikan, Bandung:Alfabet, 2011.

Suharsimi Arikunto, Prosedur Penelitian, Jakarta: Rineka Cipta, 2000. , Dasar-dasar Evaluasi Pendidikan, Jakarta:Bumi Aksara, 2011.

Sukardi, Evaluasi Pendidikan, Surabaya:Usaha Nasional, 2007.

Syafrudin Nurdin dan Basyirudin Usman, Guru Profesional dan Implementasi Kurikulum, Jakaarta : Ciputat Press, 2003.

T.Widodo, Metode Penelitian Kuantitatif, Surakarta:LPP dan UNS Press,2009. 